\title{
Predictors of Delinquency among Adolescents of Divorced Families
}

\author{
Nooshin Sabour Esmaeili ${ }^{1}$, Siti Nor Yaacob ${ }^{1} \&$ Rumaya Juhari ${ }^{1}$ \\ ${ }^{1}$ Family, Adolescent and Child Research Center (FACE), Universiti Putra Malaysia, Malaysia \\ Correspondence: Nooshin Sabour Esmaeili, Faculty of Human Ecology, Universiti Putra Malaysia, 43400 UPM \\ Serdang, Selangor, Malaysia. Tel: 60-1-7326-9351. E-mail: noshin_sabori_e@yahoo.com
}

Received: December 28, 2012 Accepted: June 14, 2013 Online Published: August 30, 2013

doi:10.5539/ass.v9n11p41

URL: http://dx.doi.org/10.5539/ass.v9n11p41

\begin{abstract}
Although delinquency is universal, few studies examined it from an Asian perspective, and even fewer considered adolescents of divorced families in Iran. The current study examined whether correlates of delinquency among western adolescents are similarly effective for predicting delinquency among adolescents from divorced families in the Mashhad city in Iran. Post-divorce parental conflict, maternal distress, economic hardship and parent-child relationship were regressed against delinquency. The parent-child relationship was the strongest significant predictor of self-reported delinquency.
\end{abstract}

Keywords: delinquency, adolescent, divorced families

\section{Introduction}

Delinquency is defined as engaging in illegal behavior, behavior against the law such as theft, skipping school, smoking, alcohol and drug abuse (Ingram et al., 2007). Adolescents with high level of delinquency have higher tendency toward substance abuse, commit suicide and exhibit mental health problems ( $\mathrm{Li}$, Chan, Chung \& Chui, 2010; Liu, 2004; Sanni, Udoh, Okediji, Modo \& Ezeh, 2010). Past studies (Burt, Barnes, McGue, \& Iacono, 2008; Dekovic et al., 2003; Kierkus \& Hewitt, 2009) consistently reveal that family processes are the most important contributor to delinquency among adolescents specifically in divorced families. Thus, the present study examined the correlations between selected family factors which are post-divorce parental conflict, maternal distress, economic hardship, and parent-child relationship with delinquency amongst adolescents from divorced families.

\section{Literature Review}

\subsection{Post-Divorce Parental Conflict and Adolescents' Delinquency}

Conflict between parents often increases immediately following the divorce (Amato, 2000; Noller, Feeney, Sheehan, Darlington, \& Rogers, 2008). There is considerable evidence that 8 to 15 percent of parents continue their conflict 2 to 3 years after divorce (Kelly, 2000; Kelly, 2003; King \& Heard, 1999). Numerous scholars asserted that parental conflict is significantly related to adolescents' delinquent behavior (Cui et al., 2007; Gerard et al., 2006; Housknecht \& Hango, 2006; Krishnakumar, Buehler, \& Barber, 2003; Sabour Esmaeili \& Yaacob, 2011). Krishnakumar et al. (2003) addressed the importance of parental conflict when examining its association with behavior problems in a sample of 542 European-American and 150 African-American youth aged 10 to 18 years old. Based on their finding adolescents who are exposed to parental conflict tend to engage in problem behaviors for both samples. Krishnakumar et al. (2003) asserted that parental conflict relates to youth externalizing problem behaviors through poor parental monitoring, low maternal acceptance, and higher levels of parent-youth conflict.

Gerard et al. (2006) in a longitudinal study examined the association between parental conflict and youth maladjustment. They found that parental conflict was related to negative parent-adolescent relationship, harsh discipline, and less parental involvement which contribute to externalizing behavior problems. Similary, Cui et al. (2007) examined the reciprocal relationship between marital functioning and adolescent maladjustment in a sample of 451 adolescents and their families in Iowa. They suggested that parental conflict over child rearing was associated with adolescent maladjustment and delinquency. Housknecht and Hango (2006) studied the relationship between marital conflict and children's health in a sample of 994 American children ages 8 to 14 years. Structural equation modeling (SEM) indicated that boys are more vulnerable to parental conflict and exhibited more antisocial behavior due to high levels of maternal discipline, but girls were more approved by 
their mothers than boys.

Bradford et al. (2008) examined the direct and indirect relationship between overt and covert parental conflict, parent-child conflict, and youth behavior problems in a sample of 641 school age youth, ages 12 to 18 years. They found that overt and covert parental conflict and parent-child conflict was significantly associated with antisocial behavior and depression among youth.

In sum, review of previous literatures indicates that a high level of parental conflict following divorce is detrimental for adolescents' positive development. When parents are in conflict, their ability to respond to children's emotional needs may decrease. Parental conflict also may decrease parental warmth and support that consequently lead to lax parental monitoring and control, and more use of verbal, physical and harsh punishment in disciplining and guiding adolescent children. These situations may enhance adolescents' tendency to become delinquent.

\subsection{Maternal Distress and Adolescents' Delinquency}

Studies showed that divorce and its stress lead to increased parental psychological distress which may influence parenting (Vandervalk et al., 2004) and parental relationship with children and adolescents (Amato, 2003; Gerard et al., 2006; Shelton \& Harold, 2008). Disruption in parent-adolescents relationship, less monitoring, and inconsistent discipline are the key mechanisms that place adolescents at greater risk for maladjustment, internalizing and externalizing behavior problems (Roustit et al., 2007; Shelton \& Harold, 2008).

Roustit et al. (2007) studied the relationship between family break up and family function and adolescent psychosocial maladjustment in a sample of 2346 adolescents aged 13 to 16 years in Quebec, and Montreal Canada. They found a strong link between family break up, parental psychological distress as a family function and adolescents' internalizing and externalizing disorders. Finding of this study explains the effects of parental distress by a family process model. According to this model, children who are exposed to parental distress, insecure marital attachment and marital conflict may possibly feel that their well-being is being threatened. This feeling may be expressed through behavior problems. This model also denoted that girls who experience parental distress tend to exhibit more internalizing disorders while boys exhibit more externalizing disorders.

Shelton and Harold (2008) in a study of 387 children 11 to 13 years in the United Kingdom revealed that maternal depressive symptoms have a significant effect on the mother-child relationship and maternal insecurity, which predict higher level of externalizing behavior problems among adolescents. Maternal depressive symptoms are also positively associated with parental conflict and parent-child rejection which is associated with child adjustment problems.

\subsection{Economic Hardship and Adolescents' Delinquency}

Parental economic hardship often influences delinquent behavior directly or increases the chances of such behavior (Agnew, 1992; Conger, 2005). Agnew (1992) suggested that economic hardship may contribute to negative emotion such as anger and depression which create pressure for delinquent behavior such as theft to diminish economic problems. The stress associated with economic problems also contributes to parental depression and distress, which in turn may lead to poor parenting practices such as low parent-child relationship, lack of warmth, low parental monitoring and supervision, and harsh discipline on children (Conger et al., 1992).

Leiber et al. (2009) examined the relationship between family structure, family processes, and economic resources on adolescent delinquency in a sample of 9636 African Americans, and Hispanic junior high schools adolescent in intact and non-intact (divorced, widowed, and never married mothers) families. Family process was characterized by the quality of relationship with mother, maternal supervision and control. The stepwise regression analyses indicated that family structure was not a predictor of delinquency, but the maternal attachment and supervision were determinants of delinquent behavior. Findings illustrated that adolescents who have a stronger attachment to their mothers and those who experienced more maternal supervision reported lower levels of delinquent behavior than those with weaker attachment and low supervision. Thus, the quality of parent-child bond may have a major role in the development of delinquency among adolescents. Economic problem is also related to delinquency through the family problems such as family conflict and parental harsh disciplinary techniques (Conger et al., 1994, 2002; Lempers \& Clark-Lempers, 1990; Wadworth \& Compas, 2002). Lempers, Clark-Lempers, and Simons (1989) found that economic problems lead to higher rates of adolescent delinquency and drug use through parents' inconsistent and harsh discipline.

Burrell and Roosa (2008) examined the relationship between mother's economic hardship and adolescent problem behavior among 189 adolescents in grade 4, 5, and 6. The Spanish version of Youth Self-Report scale and Child Behavior Checklist (Achenbach, 1991) were used to measure adolescent behavior problems. Finding 
of this study showed that mothers' economic hardship has a positive association with depressive symptoms. Mothers' depressive symptoms were negatively associated with parental monitoring. In general, this study found that economic hardship indirectly influences adolescent problem behavior through mother's depressive symptoms, parental monitoring, and deviant peer.

\subsection{Parent-Child Relationship and Adolescents' Delinquency}

Researchers have frequently highlighted the most important role of the quality of parent-child relationship in determining adolescents' delinquent behavior (Dekovic et al., 2004; Hair, Moore, Garrett, Ling \& Cleveland 2008; Wissink et al., 2006). For example, Dekovic (1999) found that negative parent-adolescent relationship is related to high level of externalizing behavior problems. This study revealed that adolescents who experience negative relationship with their parents are less likely to internalize their parents' values and norms. Conversely, adolescents who experience warm and positive relationship with their parents are more likely to express their thoughts, feelings and their daily activities to their parents and thus decrease the opportunities for delinquency (Kerr \& Stattin, 2000). Furthermore, parents who have a positive and strong relationship with their children spend more time to talk with them, help them with their homework, and engage in their children leisure activities that can lead to reduced tendency to become delinquent (Warr, 2005).

According to Hirschi (1969) strong and positive parent-child relationships are important. Parents who show affection to their children, establish good communication with them, and provide opportunities for them to be involved in the family, create positive and strong parent-child relationship. Youth, in turn, displaying positive behaviors and refrain from delinquency because they do not want to lose parental approval and affection. A good quality of the parent-child relationship also promotes adolescents' healthy development by fostering good peer relationship which reduces the chance of negative behavior (Reitz et al., 2006).

Hair et al. (2008) in the National Longitudinal Survey examined the influence of the parent-adolescent relationship on adolescent mental well-being and delinquency in a sample of adolescents 12 to 16 years. Multivariate regression analyses showed that positive relationships between adolescents and their mothers significantly predicted lower level of delinquency. Specifically, they suggested that adolescents who perceived supportive relationship with their parents engaged in fewer delinquent behaviors. They didn't find significant gender differences between perceived parent-adolescent relationship and delinquency. The study revealed that the relationship between parent-adolescent relationship and adolescent mental health and delinquency was consistent for both male and female.

Research also has shown a strong correlation between parent-child relationship and parenting practices such as parental monitoring and supports. These parental practices predict adolescent positive outcomes (Griffin et al., 2000; Paschall, Ringwalt, \& Flewelling, 2003; Smetana, Crean, \& Daddis, 2002). According to Griffin et al. (2000), more parental monitoring is associated with lower level of delinquency and served as a strong protective effect in boys than girls.

A study by Dekovic (2003) noted that parent-adolescent relationship characterized by levels of conflict, lack of closeness and acceptance was associated with involvement in antisocial behavior; and the association is stronger for boys than girls. They found that parents tend to punish and reject more or less monitor their sons than daughters. This study revealed that positive and strong relationships with parents promote adolescents' responsiveness to the expectations and desires of parents. Thus, it is likely to restrain adolescents from becoming involved in behavior that parents disapprove. In sum, it appears that parental divorce is negatively related to the quality of parent-child relationship. Divorced custodial mothers were less affectionate towards their adolescents, used harsh discipline and punishment, which contributed to negative outcomes such as delinquency.

Past studies highlighted above noted the significant influence of post-divorce parental conflict, maternal distress, economic hardship and the quality of parent-child relationship in the development of delinquent behavior. Thus, the present study extended prior research by investigating the predictors of delinquency among adolescents of divorced families in Iran.

\section{Method}

\subsection{Participants}

Using probability proportional to size sampling technique, a total of 800 adolescents of divorced families and their mothers recruited from Mashhad city in Iran were involved in the present study. The participants were between 15 to 18 years of age $(M=16.52, \mathrm{SD}=1.12)$. More than half $(53.02 \%)$ of the respondents were females. Fifty-three percent reported high delinquency. 


\subsection{Measures}

Post-Divorce Parental Conflict (PDPC): Post-Divorce Parental Conflict Scale (PPCS) developed by Sonnenblick and Schwarz (1992) was used to measure PDPC. The scale has 39 items asking respondents to assess parent's behavior on a 5 -point Likert scale $(1=$ "Never" to $5=$ "constantly") across the past 12 months. Higher scores on post-divorce parental conflict indicate higher conflict between parents following divorce. The Cronbach's alpha coefficient of the scale was .70 .

Maternal Distress: Maternal distress was measured by using a 20 -items version of the Centre for Epidemiological Studies-Depression (CES-D) scale (Radloff, 1977). Mothers of the respondents were asked about their feelings and behaviors in the past week. Two of the questions (frequent crying and sleeplessness) refer to behaviors in the past year. All items were standardized with a mean of 0 and a standard deviation of 1 , because response for some questions ranged from 0 to 3 and others from 0 to 4 . The Psychological Distress Index reflects the mean score across the 20 standardized items $(\alpha=.88)$. The 20 - items were used to create an index of mean depression symptoms. The score for 4 positive items were reversed so that the total score ranged from 0 to 62 . Higher scores indicate higher depression symptoms. The Cronbach's alpha coefficient for maternal distress in the present study was .93 .

Economic Hardship: Economic Hardship scale was adopted from the Iowa Farm and Rural Life Poll (Lasley, 1984). Adolescents were asked to rate the 12 items scale on a 4-point scale ranged from 1 (Never) to 4 (Very often). These items focused on changes in the family's style of living. Higher scores on the economic hardship scale indicate higher economic hardship. The Cronbach's alpha coefficient for this scale was .83 .

Parent-child Relationship: Parent-child relationship was assessed by using the Parental Bond Scale (Van Wel, 1994). This scale has eight items, measuring the extent to which adolescents identify with their parents, in matters of opinion and taste, view their parents as good role models in their lifestyle and approach to child-rearing, accept their parents as educators, whom they can learn from and accept criticism, and value their parents as friends and communication partners. Respondents responded to each item using a 4-point scale $(1=$ entirely disagree to $4=$ entirely agree). The items in the scale were highly interrelated (alpha $=.87$ ) and measured a single dimension (Van Wel, 1994, 2000). The Cronbach's alpha coefficient for this scale was .81.

Delinquency: Achenbach's Youth Self-Report (YSR; Achenbach, 1991) was administered to examine adolescents' delinquent behavior. YSR has 13 items rated on a 3-point Likert type scale $(0=$ not true, $1=$ somewhat or sometimes true, and $2=$ very true or often true). The Cronbach's alpha coefficient for this scale was .92 . In this study the internal consistency of all study variables was adequate.

\subsection{Procedure}

The study was approved by the Mashhad Department of Education. During the session, the researcher introduced and explained the objectives of the study to the participants. Participants were provided with a written consent form to sign and confirm their consent to participate. The researcher addressed their questions and concerns before they were given the questionnaire to complete in 20 to 30 minutes.

\section{Results}

All the measures used in this study had acceptable reliabilities ranging from .70 to .93 . Based on the group mean score displayed in Table 1, all study variables were categorized into high and low. As seen in Table 1, majority $(53.75 \%)$ of respondents perceived high level of post-divorce parental conflict. A total of $99.4 \%$ of respondents were from families with high level of economic hardship and more than half $(58.87 \%)$ of the respondents were in the low level category for parent-child relationship. Table 1 also showed that majority (53.5\%) of respondents had delinquency score above the score mean while $46.5 \%$ of respondents had delinquency score below the score mean. According to Radloff (1977) for maternal distress scale a score of 16 or higher has been used extensively as the cut-off point for high depressive symptoms. Based on Table 1, majority (99.4\%) of the respondents' mothers were in high category of distress. The skewness value for all variables was between -2 and +2 , suggesting no violation of the assumption of normality. 
Table 1. Psychometric properties of the major study variables

\begin{tabular}{|c|c|c|c|c|c|c|c|}
\hline Variable & Mean & SD & Min & Max & Skew & $\mathrm{n}$ & $\%$ \\
\hline Post-divorce parental conflict & 142.11 & 4.39 & 132 & 154 & .129 & & \\
\hline Low $($ score $\leq 142.11)$ & & & & & & 370 & 46.25 \\
\hline High (score $\geq 142.12$ ) & & & & & & 430 & 53.75 \\
\hline Maternal distress & 43.48 & 9.57 & 12 & 60 & -.520 & & \\
\hline Low (scores $\leq 15$ ) & & & & & & 5 & .6 \\
\hline High (scores $\geq 16$ ) & & & & & & 795 & 99.4 \\
\hline Economic hardship & 38.21 & 1.69 & 35 & 40 & .194 & & \\
\hline Low (scores $\leq 38.21$ ) & & & & & & 418 & 52.25 \\
\hline High (scores $\geq 38.22$ ) & & & & & & 382 & 47.75 \\
\hline Parent-child relationship & 20.96 & 4.99 & 11 & 30 & .130 & & \\
\hline Low (scores $\leq 20.96$ ) & & & & & & 471 & 58.87 \\
\hline High (scores $\leq 20.97$ ) & & & & & & 329 & 41.13 \\
\hline Delinquency & 7.63 & 6.71 & 0 & 26 & .356 & & \\
\hline Low $($ scores $\leq 7.63$ ) & & & & & & 372 & 46.5 \\
\hline High (scores $\leq 7.64$ ) & & & & & & 428 & 53.5 \\
\hline
\end{tabular}

The Pearson product-moment correlation was used to determine the relationships between post-divorce parental conflict, maternal distress, economic hardship, parent-child relationship and delinquency among adolescents of divorced families. As seen in Table 2, a statistically significant, strong and positive correlation was found between post-divorce parental conflict and adolescent delinquency $(\mathrm{r}=.775, p<.01)$. Table 2 also shows that there was a statistically significant, strong and positive correlation between maternal distress and adolescents' delinquency $(\mathrm{r}=.768, p<.01)$, a strong and positive correlation between economic hardship and adolescents' delinquency $(\mathrm{r}=.722, p<.01)$ and a statistically significant, strong and negative relationship between parent-child relationship and adolescent delinquency $(\mathrm{r}=-.876, p<.01)$.

Table 2. Relationships between independent variables and adolescents' delinquency $(\mathrm{N}=800)$

\begin{tabular}{lc}
\hline Variable & $\boldsymbol{r}$ \\
\hline Post-divorce parental conflict & $.775^{* *}$ \\
Maternal distress & $.768^{* *}$ \\
Economic hardship & $.722^{* *}$ \\
Parent-child relationship & $-.876^{* *}$ \\
\hline
\end{tabular}

Note. ${ }^{* *} p \leq .01$

Multiple regression analysis was employed to determine predictors of delinquency among adolescents of divorced families. The result of the multiple regression analysis on delinquency is presented in Table 3 . According to Table 3, the model explained $56.9 \%$ of the variance in delinquency. The highest Beta value $(\mathrm{Beta}=.57, p \leq .001)$ is for parent-child relationship. This means that parent-child relationship has the strongest, unique contribution to the prediction of delinquency among adolescents of divorced families, when the variance explained by all other variables in the model is controlled for. The Beta value for maternal distress (Beta $=.17$, $p \leq .001$ ) and economic hardship (Beta $=-.28, p \leq .001$ ) was slightly lower, indicating a lesser contribution compared to the parent-child relationship. 
Table 3. Results of multiple regression analysis for adolescents' delinquency

\begin{tabular}{lcccc}
\hline Variable & B & SE B & Beta & t \\
\hline Constant & 16.36 & 1.93 & & \\
Post-divorce parental conflict & .008 & .013 & .016 & .62 \\
Maternal distress & .23 & .012 & $.17^{* * *}$ & 2.34 \\
Economic hardship & -.17 & .017 & $-.28^{* * *}$ & -9.93 \\
Parent-child relationship & .23 & .011 & $.57^{* * *}$ & 19.97 \\
\hline
\end{tabular}

Note. $\mathrm{B}=$ unstandardized regression coefficient, Beta $=$ standardized regression coefficient, ${ }^{* * *} p<.001$

Findings revealed that parent-adolescent relationship emerged as the strongest predictor of adolescents' delinquency. Poor relationship with mothers contributes to the development of high delinquency among adolescents of divorced families whereas, high positive relationship with mothers leads to low delinquent behavior among adolescents of divorced families. These results are in line with the previous research findings (Cui et al., 2007; Davidson \& Cardemil, 2009; Dekovic et al., 2004; Demuth \& Brown, 2004; Huff et al., 2003) which suggest that the quality of parent-child relationship such as low level of parental warmth, acceptance, affection, communication, supervision, monitoring and involvement are amongst the important factors in predicting adolescents' delinquency. According to Huff, Widner and McCoy (2003), through parent-child relationship, adolescents learn appropriate behavior that can help them build healthy relationships and become responsible adults. On the other hand, positive and strong relationships with parents promote adolescents' responsiveness to the expectations and desires of parents that restrain adolescents from behavior that parents disapprove (Deckovic, 2003).

\section{Conclusions}

The purpose of this study was to determine the predictors of adolescents' delinquency in divorced families. The present study found that there is a significant relationship between post-divorce parental conflict, maternal distress, economic hardship, parent-child relationship and adolescent delinquency. This means that adolescents who experienced high levels of post-divorce parental conflict, high maternal distress, higher economic hardship and poor quality of the parent-child relationship tend to exhibit higher levels of delinquency. This study also found that parent-child relationship is the strongest predictor of an adolescents' delinquency. The result of this study appeared that adolescents who experience warm, open and intimate relationship with their mothers are less likely to not involve in delinquent behaviors.

The findings of this study should be viewed in term of its limitations. First, the sample of this study is limited to adolescent females and males of high school, ages 15 to 18 years old, in Mashhad/Iran. Thus, the findings should not be generalized beyond this population. Secondly, this study is cross-sectional in nature. Therefore, the findings cannot demonstrate causal relations between the variables studied.

Based on the present results, it is recommended that future research needs to examine other factors such as adjustment of the custodial parent, family and friend support, and the role of grandparents on adolescent's delinquency in divorced families. This study was conducted in Mashhad, Iran; therefore, the results cannot be generalized to other populations. It is recommended to conduct separate studies in several different parts of the country and in different demographic areas. The present study focused on adolescents aged between 15 and 18 years old. It is suggested that future studies should also explore younger adolescents (11 to14 years old).

\section{References}

Achenbach, T. M. (1991). Manual for the child behavior checklist, 4-18. Burlington: University of Vermote, Department of Psychiatry.

Agnew, R. (1992). Foundation for a general strain theory of crime and delinquency. Criminology, 30(1), 47-87. http://dx.doi.org/10.1111/j.1745-9125.1992.tb01093.x

Agnew, R., Matthews, S. K., Bucher, J., Welcher, A. N., \& Keyes, C. (2008). Socioeconomic status, economic problems, and delinquency. Youth and Society, 40(2), 159-181. http://dx.doi.org/10.1177/0044118X08318119

Amato, P. R. (2000). The consequences of divorce for adults and children. Journal of Marriage and the Family, 
62(4), 1269-1287. http://dx.doi.org/10.1111/j.1741-3737.2000.01269.x

Amato, P. R. (2003). Reconciling divergent perspectives: Judit Wallerstein quantitative family research and children of divorce. Family Relations, 52(4), 332-339. http://dx.doi.org/10.1111/j.1741-3729.2003.00332.x

Bradford, K., Vaughn, L. B., \& Barber, B. K. (2008). When there is conflict: Inter parental conflict, parentalchild conflict, and youth problem behaviors. Journal of Family Issues, 29(6), 780-805. http://dx.doi.org/10.1177/0192513X07308043

Burt, S. A., Barnes, A. R., McGue, M., \& Iacono, W. G. (2008). Parental divorce and adolescent delinquency: Ruling out the impact of common genes. Developmental Psychology, 44(6), 1668-1677. http://dx.doi.org/10.1037/a0013477

Conger, R. D. (2005). The Effects of Poverty and Economic Hardship across Generations. A report prepared for California Department of Social Services, 1-39.

Conger, R. D., \& Conger, K. J. (2002). Resilience in Midwestern families: Selected findings from the first decade of a prospective, longitudinal study. Journal of Marriage and Family, 64(2), 361-373. http://dx.doi.org/10.1111/j.1741-3737.2002.00361.x

Conger, R. D., Ge, X., Elder, G. H., Jr., O., Lorenz, F., \& Simons, R. L. (1994). Economic stress, coercive family process, and developmental problems of adolescents. Child Development, 65(2), 541-561. http://dx.doi.org/10.2307/1131401

Conger, R. D., Conger, K. J., Elder, G. H., Jr. O., Lorenz, F., Simons, R. L., \& Whitbeck, L. B. (1992). A family process model of economic hardship and adjustment of early adolescent boys. Child Development, 63(3), 526-541. http://dx.doi.org/10.2307/1131344

Cui, M., Donnellan, M. B., \& Conger, R. D. (2007). Reciprocal influences between parents' marital problems and adolescent internalizing and externalizing behavior. Developmental Psychology, 43(6), 1544-1552. http://dx.doi.org/10.1037/0012-1649.43.6.1544

Davidson, T. M., \& Cardemil, E. V. (2009). Parent-child communication and parental involvement in Latino adolescents. The Journal of Early Adolescence, 29(1), 99-121. http://dx.doi.org/10.1177/0272431608324480

Dekovic, M. (1999b). Risk and protective factors in the development of problem behavior during adolescence. Journal of Youth and Adolescence, 28(6), 667-685. http://dx.doi.org/10.1023/A:1021635516758

Dekovic, M., Janssens, J. M. A. M., \& Van As, N. M. C. (2003). Family predictors of antisocial behavior in adolescence. Family Process, 42(2), 223-235. http://dx.doi.org/10.1111/j.1545-5300.2003.42203.x

Dekovic, M., Wissink, I. B., \& Meijer, A. M. (2004). The role of family and peer relations in adolescent antisocial behavior: Comparison of four ethnic groups. Journal of Adolescence, 27, 497-514. http://dx.doi.org/10.1016/j.adolescence.2004.06.010

Demuth, S., \& Brown, S. L. (2004). Family structure, family processes and adolescent delinquency: The significance of parental absence versus parental gender. Journal of Research in Crime and Delinquency, 41(1), 58-81. http://dx.doi.org/10.1177/0022427803256236

Gerard, J. M., Krishnakumar, A., \& Buehler, C. (2006). Marital conflict, parent-child relations, and youth maladjustment: A longitudinal investigation of spill-over effects. Journal of Family Issues, 27(7), 951-975. http://dx.doi.org/10.1177/0192513X05286020

Griffin, K. W., Botvin, G. J., Scheier, L. M., Diaz, T., \& Miller, N. L. (2000). Parenting practices as predictors of substance use, delinquency, and aggression among urban minority youth: Moderating effects of family structure and gender. Psychology of Addictive Behaviors, 14(2), 174-184. http://dx.doi.org/10.1037//0893-164X.14.2.174

Hirschi, T. (1969). Causes of delinquency. Berkeley, CA: University of California Press.

Houseknecht, S. K., \& Hango, D. W. (2006). The impact of marital conflict and disruption on children's health. Youth and Society, 38(1), 58-89. http://dx.doi.org/10.1177/0044118X06287862

Huff, C., Widner, M., \& Mccoy, K. (2003). The influence of challenging outdoor reaction parent-adolescent communication. Therapeutic Recreation Journal, 37, 18-37.

Ingram, J. R., Patchin, J. W., Huebner, B. M., McCluskey, J. D., \& Bynum, T. S. (2007). Parents, friends, and serious delinquency: An examination of direct and indirect effects among at risk early adolescents. Criminal 
Justice Review, 32(4), 380-400. http://dx.doi.org/10.1177/0734016807311436

Kelly, J. B. (2000). Children's adjustment in conflicted marriage and divorce: A decade review of research. Journal of the American Academy of Child and Adolescent Psychiatry, 39(8), 963-973. http://dx.doi.org/10.1097/00004583-200008000-00007

Kelly, J. B. (2002). Psychological and legal interventions for parents and children in custody and access disputes: Current research and practice. Virginia Journal of Social Policy and the Law, 10(1), 129-163.

Kelly, J. B. (2003). Changing perspectives on children's adjustment following divorce: A review from the United States. Childhood, 10(2), 237-254. http://dx.doi.org/10.1177/0907568203010002008

Kerr, M., \& Stattin, H. (2000). What parent know, how they know it, and several forms of adolescent adjustment. Developmental Psychology, 36(3), 366-380. http://dx.doi.org/10.1037/0012-1649.36.3.366

Kierkus, C. A., \& Hewitt, J. D. (2009). The contextual nature of the family structure/delinquency relationship. Journal of Criminal Justice, 37(2), 123-132. http://dx.doi.org/10.1016/j.jcrimjus.2009.02.008

King, V., \& Heard, H. E. (1999). Non-resident father visitation, parental conflict, and mother's satisfaction: What's best for child well-being? Journal of Marriage and the Family, 61(2), 385-396. http://dx.doi.org/10.2307/353756

Krishnakumar, A., Buehler, C., \& Barber, B. K. (2003). Youth perceptions of inter parental conflict, ineffective parenting, and youth problem behaviors in European-America and African-American families. Journal of Social and Personal Relationships, 20(2), 239-260.

Lasley, P. (1984). Iowa farm and rural life poll. Ames: Cooperative Extension Service. Iowa State University.

Leiber, M. J., Mack, K. Y., \& Featherstone, R. A. (2009). Family structure, family processes, economic factors, and delinquency: Similarities and differences by race and ethnicity. Youth Violence and Juvenile Justice, 7(2), 79-99. http://dx.doi.org/10.1177/1541204008327144

Lempers, J. D., \& Clark-Lempers, D. (1990). Family economic stress, maternal and paternal support and $\begin{array}{lllll}\text { adolescent distress. Journal of } & \text { Adolescence, } & 13(3), & \text { 217-229. }\end{array}$ http://dx.doi.org/10.1016/0140-1971(90)90015-Y

Li, H. C. W., Chan, S. L. P., Chung, O. K. J., \& Chui, M. L. M. (2010). Relationships among mental health, self-esteem and physical health in Chinese adolescents: An exploratory study. Journal of Health Psychology, 15(1), 96-106. http://dx.doi.org/10.1177/1359105309342601

Liu, R. X. (2004). The conditional effects of gender and delinquency on the relationship between emotional distress and suicidal ideation or attempt among youth. Journal of Adolescent Research, 19(6), 698-715. http://dx.doi.org/10.1177/0743558403260020

Noller, P., Feeney, J. A., Sheehan, G., Darlington, Y., \& Rogers, C. (2008). Conflict in divorcing and continuously married families: A study of marital, parent-child and sibling relationships. Journal of Divorce and Remarriage, 49(1), 1-24. http://dx.doi.org/10.1080/10502550801971223

Paschall, M. J., Ringwalt, C. L., \& Flewelling, R. L. (2003). Effects of parenting, father absence, and affiliation with delinquent peers on delinquent behavior among African-American male adolescents. Adolescence, 38, 15-34.

Radloff, L. (1977). The CES-D scale: A self-report depression scale for research in the general population. Applied Psychological Measurement, 1, 385-401. http://dx.doi.org/10.1177/014662167700100306

Reitz, E., Dekovic, M., Meijer, A. M., \& Engles, R. C. M. E. (2006). Longitudinal relations among parenting, best friends, and early adolescent problem behaviour: Testing bidirectional effects. The Journal of Early Adolescence, 26(3), 272-295. http://dx.doi.org/10.1177/0272431606288591

Roustit, C., Chaix, B., \& Chauvin, P. (2007). Family breakup and adolescents' psychosocial maladjustment: Public health implications of family disruptions. Pediatrics, 120(4), 984-991. http://dx.doi.org/10.1542/peds.2006-3172

Sabour Esmaeili, N., \& Yaacob, S. N. (2011). Post-divorce parental conflict and adolescents' delinquency in divorced families. Asian Culture and History, 3(2), 34-40.

Sanni, K. B., Udoh, N. A., Okediji, A. A., Modo, F. N., \& Ezeh, L. N. (2010). Family types and juvenile delinquency issues among secondary school students in Akwa Ibom State, Nigeria: Counseling implications. Journal of Social Science, 23(1), 21-28. 
Shelton, K. H., \& Harold, G. T. (2008). Inter parental conflict, negative parenting, and children's adjustment: Bridging links between parents' depression and children's psychological distress. Journal of Family Psychology, 22(5), 712-724. http://dx.doi.org/10.1037/a0013515

Smetana, J. G., Crean, H. F., \& Daddis, C. (2002). Family processes and problem behaviors in middle-class African American adolescents. Journal of Research on Adolescence, 12(2), 275-304. http://dx.doi.org/10.1111/1532-7795.00034

Sonnenblick, R., \& Schwarz, J. C. (1992). The development of the post-divorce parental conflict scale. Poster presented at the Centennial Annual Convention of the American Psychological Association at Wasshington, D.C.

Van Wel, F. (1994). "I count my parents among my best friends": Youths' bonds with parents and friends in the Netherlands. Journal of Marriage and Family, 56(4), 835-843. http://dx.doi.org/10.2307/353596

Van Wel, F., Hub, L., \& Ruud, A. (2000). The parental bond and the well-being of adolescent and young adults. Journal of Youth and Adolescence, 29(3), 307-318. http://dx.doi.org/10.1023/A:1005195624757

Vandervalk, I., Spruijt, E., Goede, M., Maas, C., \& Meeus, W. (2004). Marital status, marital process, and parental resources in predicting adolescent emotional adjustment: A multilevel analysis. Journal of Family Issues, 25(3), 291-317. http://dx.doi.org/10.1177/0192513X03257429

Wadsworth, M. E., \& Compas, B. E. (2002). Coping with economic strain and family conflict: The adolescent perspective. Journal of Research on Adolescence, 12(2), 243-274. http://dx.doi.org/10.1111/1532-7795.00033

Warr, M. (2005). Making delinquent friends: Adult supervision and children's affiliations. Criminology, 43(1), 77-106. http://dx.doi.org/10.1111/j.0011-1348.2005.00003.x

Wissink, I. B., Dekovic, M., \& Meijer, A. M. (2006). Parenting behavior, quality of the parent-adolescent relationship, and adolescent functioning in four ethnic groups. The Journal of Early Adolescence, 26(2), 133-159. http://dx.doi.org/10.1177/0272431605285718

\section{Copyrights}

Copyright for this article is retained by the author(s), with first publication rights granted to the journal.

This is an open-access article distributed under the terms and conditions of the Creative Commons Attribution license (http://creativecommons.org/licenses/by/3.0/). 